\title{
The Success of the "Kasira" Rabies Cadres in Improving Community Knowledge and Attitudes towards Rabies
}

\author{
Etih Sudarnika \\ Department of Animal Disease and \\ Veterinary Public Health, Faculty of \\ Veterinary Medicine \\ IPB University (Bogor Agricultural \\ University) \\ Bogor, Indonesia \\ etih@apps.ipb.ac.id \\ Yusuf Ridwan \\ Department of Animal Disease and \\ Veterinary Public Health, Faculty of \\ Veterinary Medicine \\ IPB University (Bogor Agricultural \\ University) \\ Bogor, Indonesia \\ Yridwan67@gmail.com
}

\author{
Denny Widaya Lukman \\ Department of Animal Disease and \\ Veterinary Public Health, Faculty of \\ Veterinary Medicine \\ IPB University (Bogor Agricultural \\ University) \\ Bogor, Indonesia \\ dennylukman@hotmail.com \\ Ardilasunu Wicaksono \\ Department of Animal Disease and \\ Veterinary Public Health, Faculty of \\ Veterinary Medicine \\ IPB University (Bogor Agricultural \\ University) \\ Bogor, Indonesia \\ vetsunuedu@gmail.com
}

\author{
Abdul Zahid \\ Department of Animal Disease and \\ Veterinary Public Health, Faculty of \\ Veterinary Medicine \\ IPB University (Bogor Agricultural \\ University) \\ Bogor, Indonesia \\ abdul.zahid_ilyas@yahoo.com
}

\begin{abstract}
Community-based approach, named kasira (rabies cadres) was developed in Sukabumi to overcome obstacles in rabies control program. The aims of this study were to evaluate the ability of rabies cadres in educating the people in their community relating to improving people's knowledge and attitudes, and their responses to the information media disseminated. Respondents consisted of 200 people who were participants in the education program delivered by kasira in all villages (11 villages) in Jampang Tengah Subdistrict, Sukabumi Regency. The educational method were classical and face to face communication, distribution of banners, posters, and leaflets. Pre-test and post-test were given to participants before and after the activity. Participants also filled out questionnaires related to activities and their response to information media that were distributed. The t-test for paired data was used to measure the increase in knowledge and attitudes after activity. The results showed that the percentage of participants who had good knowledge of rabies increased from $26.5 \%$ to $72.5 \%$, and the percentage who had positive attitude toward rabies controlling increase from $19 \%$ to $56.5 \%$, and the interventions can significantly increase respondents' knowledge and attitudes. The involvement of integrated health cadres in controlling and eradicating rabies is very important, especially for communication, education and information to the community.
\end{abstract}

Keywords-integrated health post cadres, kasira, rabies, rabies cadres

\section{INTRODUCTION}

Rabies is one of the major zoonotic problems in Indonesia. Most cases of rabies occur in rural areas. The obstacles encountered in rabies control are low coverage of rabies vaccination because some dogs are free raring so difficult to handle, low public awareness about rabies, delayed reports of bite cases, lack of coordination between human health and animal health workers, lack of public knowledge about rabies and first handling bite cases [1,2]. Beginning in 2017, Rabies Cadres (kasira="kader siaga rabies") was formed in every village in Jampang Tengah Subdistrict of Sukabumi Regency, West Java.

The program was begun with the establishment of rabies cadres institution, rabies cadres (kasira), the development of Standard Operational Procedure (SOP) related rabies and training of trainers on rabies cadres (Kasira) and institution of Kasira members. Kasira training materials included The introduction of rabies, The first aid for dog-bite cases, The dog handling and vaccination, The communication techniques, The cases reporting and introduction of SOP related rabies. Training for Kasira institution members included communication and leadership. Kasira's task were to educate community about rabies, assist in the implementation of mass rabies vaccination programs conducted by the local government, conduct first aid and reporting when there were dog bite cases, assist local health workers and animal health workers in investigating rabies cases and rabies control programs, and register dogs in their areas[3]. 
Kasira was volunteer persons who consisting of local village communities namely integrated health post cadres, hunters' representatives, village officials, village territorial advisor (army) and village security advisor (police). Kasira from integrated health cadres was one of the most important, because they have a responsibility to give the education to the other integrated health cadres and the villagers, assisting campaign programs on rabies vaccination, conduct first aid and reporting when there were dog bite cases, and register dogs in their areas.

The aims of this study were to evaluate the ability of rabies cadres in educating the people in their community relating to improving people's knowledge and attitudes, and their response to the information media disseminated.

\section{MATERIALS AND METHODS}

Respondents consisted of 200 people who were participants in the education program in all villages (11 villages) in Jampang Tengah Subdistrict, Sukabumi Regency. Participants were integrated health post (posyandu) cadres in each village. Education was delivered by a kasira in the village. The educational method was classical and face to face communication, distribution of banners, posters, and leaflets.

Pre-test was given to participants before the educational activity begins, and a post-test was carried out after the activity. In addition to pre-test and post-test, participants also filled out questionnaires related to educational activities and their response to information media in the form of leaflets, posters and banners that were distributed.

Data Analysis were presented in a table, and the t-test for paired data was used to measure the increase in knowledge and attitudes after an educational activity were carried out by kasira.

\section{RESULTS}

\section{A. Respondents Characteristics}

The characteristics of respondents was a description of a special situation of respondents. The respondents were integrated health post (posyandu) cadres in each village. The characteristics of integrated health post cadres consist of age, level of education, sex, having attended education program related rabies in the past year and dog ownership.

Most respondents (61.5\%) were aged between 25 - 44 years, had elementary and high school education, and the majority were women. Most of the respondents said they had never received an education related to rabies and in general they did not have a dog.

The level of education and element had a significant relationship with the knowledge level $(\mathrm{P}=0.001, \mathrm{P}=0.014)$. Age had a significant relationship with attitude level $(\mathrm{P}=0.045)$.
TABLE 1. DISTRIBUTION OF RESPONDENTS CHARACTERISTICS

Characteristics

n $(\%)$

\begin{tabular}{|c|c|}
\hline Age (year) & \\
\hline $15-24$ & $28(14.0)$ \\
\hline $25-34$ & $60(30.0)$ \\
\hline $35-44$ & $63(31.5)$ \\
\hline $45-54$ & $33(16.5)$ \\
\hline$\geq 55$ & $9(4.5)$ \\
\hline Not answer & $7(3.5)$ \\
\hline \multicolumn{2}{|l|}{ Formal Education } \\
\hline Elementary & $66(33.0)$ \\
\hline \multicolumn{2}{|l|}{ School } \\
\hline Junior & $55(27.5)$ \\
\hline \multicolumn{2}{|l|}{ School } \\
\hline Senior & $65(32.5)$ \\
\hline \multicolumn{2}{|l|}{ School } \\
\hline University & $11(5.5)$ \\
\hline Not answer & $3(1.5)$ \\
\hline \multicolumn{2}{|l|}{ Sex } \\
\hline Male & $20(10.0)$ \\
\hline Female & $180(90.0)$ \\
\hline \multicolumn{2}{|l|}{$\begin{array}{l}\text { Having attended } \\
\text { extension related rabies } \\
\text { in the past year }\end{array}$} \\
\hline 1 time & $61(30.5)$ \\
\hline 2 time & $11(5.5)$ \\
\hline 3 time or more & $6(3.0)$ \\
\hline Never & $122(61.0)$ \\
\hline \multicolumn{2}{|l|}{ Dog ownership } \\
\hline Yes & $12(6.0)$ \\
\hline No & $188(94.0)$ \\
\hline
\end{tabular}

\section{B. Knowledge and Attitude of Respondents Before and} After Intervention

The pre-test and post-test scores of knowledge were categorized as poor (0-16), moderate (17-22) and good (23-30). Pre-test and post-test attitudes scores were categorized into negative (0-10), neutral (11-14), and positive (15-20) grades.

Table 2 showed that respondents who received a pretest score of knowledge in the good category numbered $26.5 \%$ and after the activity increased to $72.5 \%$. The number of respondents who received positive attitude scores was $19.0 \%$ and after the intervention increased to $56.5 \%$. From Table 3 it was known that the respondents who increased their knowledge were 116, while the score decreased by 10 and the scores were the same as 74 . Respondents who increased their attitude score were 117 , while 12 respondents decreased and 71 got the same score. Table 3 also showed that educational activity interventions can significantly increase respondent's knowledge and attitudes $(\mathrm{p}=0.00)$. 
TABLE II. DisTRIBUTION OF THE LEVEL OF KNOWLEDGE AND ATTITUDE OF RESPONDENTS BEFORE AND AFTER THE INTERVENTION

\begin{tabular}{lcccccc}
\hline \multicolumn{4}{c}{ Knowledge } & \multicolumn{4}{c}{ Attitude } \\
Test & $\begin{array}{c}\text { Poor } \\
\mathrm{n}(\%)\end{array}$ & $\begin{array}{c}\text { Moderate } \\
\mathrm{n}(\%)\end{array}$ & $\begin{array}{c}\text { Good } \\
\mathrm{n}(\%)\end{array}$ & $\begin{array}{c}\text { Negative } \\
\mathrm{n}(\%)\end{array}$ & $\begin{array}{c}\text { Neutral } \\
\mathrm{n}(\%)\end{array}$ & $\begin{array}{c}\text { Positive } \\
\mathrm{n}(\%)\end{array}$ \\
\hline Pre- & 39 & 108 & 53 & 76 & 86 & 38 \\
test & $(19.5)$ & $(54.0)$ & $(26.5)$ & $(38.0)$ & $(43.0)$ & $(19.0)$ \\
Post- & 4 & 51 & 145 & 13 & 74 & 113 \\
test & $(2.0)$ & $(25.5)$ & $(72.5)$ & $(6.5)$ & $(37.0)$ & $(56.5)$ \\
\hline
\end{tabular}

TABLE III. DIFFERENCES IN RESPONDENTS' KNOWLEDGE AND

\begin{tabular}{crc}
\multicolumn{3}{c}{ ATTITUDES SCORES AFTER THE INTERVENTION } \\
\hline Variable & $\mathrm{n}$ & $\mathrm{p}$-value \\
\hline Knowledge & 10 & $0.000^{*}$ \\
post-test score $<$ pre-test score & 116 & \\
post-test score $>$ pre-test score & 74 & \\
post-test score $=$ pre-test score & 12 & $0.000^{*}$ \\
Attitude & 117 & \\
post-test score $<$ pre-test score & 71 & \\
post-test score $>$ pre-test score & & \\
post-test score $=$ pre-test score &
\end{tabular}

\section{Evaluation of Educational Activities by Respondents}

Most of Kasira had good abilities in delivering educational material. The evaluation results of the participants presented in Table 4 showed that more than 90 percent of participants said that the material was clear, the room was comfortable, teaching materials were available and they were happy to participate. More than $85 \%$ of the participants also stated that they were not ashamed and afraid in expressing their opinions.

TABLE IV. Results Of EVALUATION OF EdUCATIONAL ACTIVITIES By

\begin{tabular}{ll}
\multicolumn{2}{c}{ PARTICIPANTS } \\
\hline \multicolumn{2}{c}{$\mathrm{n}(\%)$} \\
$\begin{array}{l}\text { Presentation of the material was } \\
\text { clear }\end{array}$ \\
$\quad$ Yes & $199(99.5)$ \\
No & $1(0.5)$ \\
The room is comfortable & $198(99.0)$ \\
Yes & $2(1.0)$ \\
No & $197(98.5)$ \\
Teaching materials available & $3(1.5)$ \\
Yes & $187(93.5)$ \\
No & $13(6.5)$ \\
Participants feel happy & \\
Yes & \\
No & $175(87.5)$ \\
Participants were not ashamed to \\
express their opinions
\end{tabular}

\section{Respondents' responses to Leaflets, Posters and Banners}

Information media related to rabies has been distributed in all villages in Jampang Tengah Sub district. The information media developed were leaflets, posters and banners. Leaflets and posters were distributed at integrated health post to be disseminated during their activities. The banners were placed in each Village Office.
TABLE V. Distribution Of Respondents Who Had SEEN AND ReAd LEAFLETS, POSTERS AND BANNERS

\begin{tabular}{ll}
\hline Variables & $\mathrm{n}(\%)$ \\
\hline Had seen leaflet & $160(80.0)$ \\
Yes & $40(20.0)$ \\
No & $154(77.0)$ \\
Had read leaflet & $46(23.0)$ \\
Yes & $162(81.0)$ \\
No & $38(19.0)$ \\
Had seen poster & $151(75.5)$ \\
Yes & $49(24.5)$ \\
No & $137(68.5)$ \\
Had read poster & $63(31.5)$ \\
Yes & $131(65.5)$ \\
No & $69(34.5)$ \\
Had seen banner & \\
Yes & \\
No & \\
Had read banner & Yes \\
No &
\end{tabular}

From the results of evaluations of integrated health post cadres conducted in each village, it appeared that most integrated health post cadres had seen and read these media (Table 5). Integrated health post cadres had a good willingness to read. This could be seen from the percentage of integrated health post cadres who had read leaflets, posters and banners by more than $90 \%$ among who had seen them.

\section{DISCUSSION}

Kasira from Integrated Health Cadres have an important role in controlling and eradicating rabies in Sukabumi Regency. Integrated health cadres is a group of volunteers in the field of public health that has been established and is available in all sub villages. These cadres have a closeness and are part of the community, so they can disseminate and transform information more quickly.

This research showed that Kasira from Integrated Health Cadres had a good ability to educate the public, which in this study were Integrated Health Cadres in their village. They were able to increase the percentage of participants who had good knowledge of rabies from $26.5 \%$ to $72.5 \%$, and the percentage who had positive attitude toward rabies controlling from $19 \%$ to $56.5 \%$.

The evaluation results of the participants also showed that Kasira had a good ability in preparing educational activities, including places, teaching materials and presentations, as well as methods for delivering learning. The interesting thing was that most of the integrated health cadres in Jampang tengah Sub district have a very good interest in reading. More than $90 \%$ of cadres who said that they had seen the leaflet, posters and banners, they also read them. The percentage of cadres who read leaflets and banners was higher than posters, namely $95 \%$ for leaflets and banners, and $93 \%$ for posters. The involvement of integrated health cadres in controlling and eradicating 
rabies is very important, especially for communication, education and information to the community.

\section{CONCLUSION}

The engagement of integrated health post cadres as rabies cadres (kasira) has an important role in the rabies control program. They have good ability in the process of education and information dissemination related to rabies. Their presence which is widespread to remote villages enables the acceleration of information and education related to rabies.

\section{ACKNOWLEDGMENT}

We thank Ministry of Research Technology and Higher Education for funding this activity. We also thank all the rabies cadres, the animal health workers and public health workers of Sukabumi District, Students of Faculty of Veterinary Medicine of IPB, and all the team member.

\section{REFERENCES}

[1] V Safitri, E Sudarnika, and DW Lukman, "Release assessment ofiIntroducing rabies virus from Distric of Sukabumi into Jakarta Province through dogs", Global Veterinaria, vol. 14 (2), pp. 178184, 2015.

[2] G Gongal and AE Wright, "Human rabies in the WHO Southeast Asia Region: forward steps for elimination", Advances in Preventive Medicine. 2011, pp.1-5, 2011.

[3] F Hidayati, E Sudarnika, H Latif, DW Lukman, Y Ridwan, A Zahid, A Wicaksono, "Community-based participation intervention to enhancing knowledge and attitudes of preparedness rabies cadres in rabies control in Sukabumi District", Proceedings: 2018 International Research Symposium Series (IRSS) Penang \& Jakarta (March 2018) pp. 1-8, 2018. 